\title{
Management of Municipal Solid Waste in Côte d'Ivoire: Current Situation and Perspectives to Green Job Creation
}

\author{
Bodjui Olivier Abo* and Moussa Bakayoko \\ Department of Environmental Engineering, University of Science and Technology Beijing, China
}

Submission: September 09, 2018; Published: September 20, 2018

*Corresponding author: Bodjui Olivier Abo, Department of Environmental Engineering, University of Science and Technology Beijing, China, Email: abobodjuiolivier@yahoo.com

\section{Mini Review}

In Côte d'Ivoire, the average daily production of waste per capita is between $0.2 \mathrm{~kg} / \mathrm{HBT} /$ day and $0.8 \mathrm{~kg} / \mathrm{HBT} /$ day. This waste is more than $60 \%$ composed of fermentable organic matter. Waste production is estimated in 2015 to 2996537 tons for an urban population of 9753573 inhabitants at the level of the 34 localities of the country. The waste produced is very rich in organic matter and recyclable materials. Fermentable materials represent more than one million tons in 2015. All this quantity is found in wild landfills contributing to the phenomenon of climate change through the production of greenhouse gases $(\mathrm{CH} 4, \mathrm{CO} 2$, etc.). The energy potential of these fermentable materials can be valorized by the exploitation of biogas. Recyclable materials represent a quantity of 367525 tons consisting of plastics (144 458 tons), paperboard (137 041 tons), textiles (55 344 tons) metals (18 936 tons) and glasses (11 745 tons). At this level, recovery, reuse and recycling can make them more valuable. The rational exploitation of this deposit could have positive impacts on the entire household solid waste management chain through the production of financial resources that will allow the sector to self-finance [1].

Since the years 60 until 2007, the management of solid household waste has always been a prerogative of the territorial authorities which had in charge the whole sector, from the pre-collection in the households to the landfill through the collection and the transport of household waste. In order to consolidate the process of decentralization in the field of urban health management, the Government of Côte d'Ivoire, in 2002, developed a national strategy for the management of domestic solid waste. However, the execution of schemas gave mixed results and in the face of the growing unhealthy in the Ivorian Cities, Ordinance No. 2007-586 of 2007 October 4 entrusted the management of household solid waste and assimilated to a centralized entity what is the Ministry of the City and urban health, through the National Agency for Urban Safety (ANASUR). This state structure is responsible for organizing, supervising the execution of collection, transport and landfill operations. In practice, a real confusion arose from the interpretation of this Ordinance in relation to the roles of the ANASUR and those of the town halls. This confusion between the actors in the sector has been the shortcomings both at the legal and institutional level leading to poor governance in the sector. At the technical and financial level, the inefficiency of waste management is attributable to shortcomings in the technical organization of activities and the problems of sustainable financing. These organizational dysfunctions result in irregularity and inefficiency in the sector. At the financial level, the authorities are struggling to find sustainable financing for the sector. Thus, claimants not only charge arrears of several months but also partially pay [2] This situation strongly impacts the rate of neighborhood-level collection coverage that is less than $20 \%$ in cities in the interior of the country. For the municipalities of the District of Abidjan and the city of Yamoussoukro, this rate is estimated between 50 and $90 \%$ of the districts. The collection rate determines the quality of the collection service. In addition, uncollected waste is discharged to nature and constitutes wild deposits that degrade the quality of the population's living environment, pollute surface and groundwater resources and threaten public health through the production of Germs of diseases related to unsanitary conditions (cholera, malaria, hepatitis B, typhoid, etc.) [3]. While in the localities, it is barely $30 \%$ of the household solid waste that is collected and evacuated in landfills. On the other hand, in the communes where the activities are more or less structured, the collection rate is around $70 \%$ or more, but no Ivorian city manages to evacuate $80 \%$ of its waste production.

The forces of the sector can present themselves as follows a political will displayed by the authorities for the professionalization of the sector, the importance of the deposit with a remarkable potential value to more than $70 \%$. There is also a potential for job creation, availability of manpower and national expertise. All these factors make the sector attractive to domestic and foreign investors. However, the authorities need to decide to lift certain weights which inhibit the organisation 
of the sector in a vision of sustainable development. These shortcomings are at the level of the legal and institutional framework, the lack of a national strategy for the management of domestic solid waste, the lack of management tools at the level of the decentralised communities. The marginalization of sorting, recycling and recovery operations, the lack of knowledge of the deposit, the shortage of material, human and financial resources are also factors that weaken this sector. Despite all these shortcomings, it is important to note that a well-organized sector could benefit from many technical and financial opportunities. These opportunities are in the search for and exploitation of additional financial resources from funders and households. Similarly, the formalization of activities and the exploitation of national and international markets for the disposal of recycled and valued products are opportunities to explore. However, it is important that the state can set up mechanisms for mobilizing resources and tax facilities to attract foreign investment into the sector.

The survey of waste collectors and resellers has shown that some categories of waste have an economic interest for artisans, traders (wholesalers and retailers), industrial and commercial companies located in the markets and industrial areas of Côte d'Ivoire. The average sales prices of the recovered waste (plastics, papers, cartons, textiles, ferrous and non-ferrous metals and glasses) on the market are between $0.103 \$$ and $0.302 \$$. On the basis of this range, the economic potential of waste was estimated in 2015 to 56393298 \$. In the Abidjan District, an amount of 39 097761 \$, or $69 \%$, is estimated at the national level. For other cities, the economic potential of the sector is estimated at 17341 $959 \$$, or $31 \%$. In the light of these figures, the development of waste recovery and recycling streams is more than necessary. Unfortunately, this link is managed by the informal sector. This economic potential allowed us by analyzing the number and typology of jobs in a formal structure to make an estimate of the number of green jobs that the industry can create if it is organized. Thus, the organization of the sector will create about 23000 green jobs in 27 categories in the fields of administration and management, financial management, supervision, coaching and execution. These results are in agreement with the ILO report in 2013, which believes that the organization of the household solid waste management sector will generate thousands of green jobs in African countries [1]. However, these results can only be achieved if the Ivorian authorities engage in reform in the sector aimed at improving the legal framework and making it an incentive for private investment. In General, the solid waste stream has constraints on sustainable management. These difficulties are legal, institutional and technical. The legal framework for environmental management in Côte d'Ivoire does not have specific texts on the management of household solid waste. These legal and institutional shortcomings in the domestic solid waste sector are due to the lack of legislative and regulatory legislation specifically governing the industry. This has a repercussion on the play of the actors and the organization of the activities of the sector. At the technical level, the solid waste sector is not well organized. This is due to the lack of material and human resources. These problems affect the quality of the garbage collection service which covers only $30 \%$ of the neighborhoods in the cities of the interior of the country. The economic potential of the household solid waste sector in Côte d'Ivoire is important in view of the financial resources it could generate. The waste sector can contribute to the national employment policy. Indeed, it is a big pool of green jobs. The authorities would benefit from organizing the sector which constitutes a pathway for the absorption of unemployed and non-qualified young people.

\section{Acknowledgment}

The authors gratefully acknowledge all laboratory and schools.

\section{References}

1. BIT (2013) Analyse des potentialités de création demplois verts dans les régions de Kolda, Migration, environnement et développement locale. Matam et Saint Louis p. 1-37.

2. Dje A (2012) Gouvernance et gestion des déchets ménagers urbains à Abidjan Cas des communes de Cocody, Yopougon et Abobo, thèse de doctorat Université Laval, Québec, pp. 404.

3. Ouattara L, Soro N, Dongo K, Kouadio EK, Ahoussi K, et al. (2010) Déchets municipaux dans le District dAbidjan en Côte dIvoire sources potentielles de pollution des eaux souterraines. Int J Biol Chem Sci 4(6): 2203-2219.

This work is licensed under Creative Commons Attribution 4.0 License DOI: $10.19080 / I J E S N R .2018 .14 .555886$
Your next submission with Juniper Publishers will reach you the below assets

- Quality Editorial service

- Swift Peer Review

- Reprints availability

- E-prints Service

- Manuscript Podcast for convenient understanding

- Global attainment for your research

- Manuscript accessibility in different formats

( Pdf, E-pub, Full Text, Audio)

- Unceasing customer service

Track the below URL for one-step submission https://juniperpublishers.com/online-submission.php 